\title{
Analisis Faktor-Faktor yang Memengaruhi Kualitas Tidur Pasien Lanjut Usia dengan Penyakit Kronis
}

\author{
Analysis of Factors Affecting Sleep Quality in Elderly Patients with Chronic Disease
}

\author{
Akbar Harisa ${ }^{1}$, Syahrul Syahrul2 ${ }^{2}$ Yodang Yodang ${ }^{3 凶}$, Restu Abady $^{4}$, Abdul Gani Bas ${ }^{5}$ \\ 1,2,4,5Univeritas Hasanuddin \\ ${ }^{3}$ Universitas Sembilanbelas November Kolaka
}

\begin{abstract}
ABSTRAK
Latar Belakang: Penyakit kronis merupakan isu terkait kesehatan yang lazim ditemukan pada lansia yang dapat meningkatkan tingkat morbiditas dan mortalitas pasien lansia. Kualitas tidur pasien lansia dengan penyakit kronis dapat terganggu dan dapat menimbulkan efek buruk terhadap status kesehatan.

Tujuan: Menganalisis kualitas tidur beserta determinannya pada pasien lanjut usia dengan penyakit kronis di RS Unhas Makassar.

Metode: Penelitian ini dilakukan secara deskriptif analitik dengan metode survey cross-sectional pada pasien lanjut usia yang terdiagnosis penyakit kronis dan sedang dalam Perawatan di RS Unhas Makassarsebanyak 40 orang. Analisis data menggunakan uji Chi-Square dan uji Mann-whitney.

Hasil: Hasil penelitian ini menunjukkantidak ada pengaruh antara jumlah komorbit yang dimiliki, lama penyakit yang diderita, penggunaan obat-obatan serta status psikologis terhadap kualitas tidur pada usia lanjut. Satu-satunya risiko yang berpengaruh terhadap kualitas tidur pada penelitian ini adalah jenis kelamin dengan $p$ value 0,049 . Kualitas tidur yang buruk lebih sering terjadi ada lansia berjenis kelamin laki-laki dibandingkan dengan perempuan.

Kesimpulan: Jenis kelamin merupakan prediktor terhadap kualitas tidur lansia, sedangkan faktor lainnya tidak menunjukkan signifikansinya. Untuk penelitian selanjutnya, maka penelitian dengan penetapan kriteria sampel yang lebih selektif serta melibatkan jumlah responden yang lebih besar sangat dibutuhkan.
\end{abstract}

Kata Kunci: Kualitas tidur; lansia; jenis kelamin

\section{ABSTRACT}

Background: Chronic disease is a health problem that often occurs in the elderly. The quality of sleep of elderly patients with chronic diseases can be disturbed and can harmtheir condition.

Objective: Analyze the factors that affect the quality of sleep of elderly patients with chronic diseases in UNHAS Teaching Hospital.

Methods: This study implemented a descriptive-analytic study with a cross-sectional survey method on elderly patients diagnosed with chronic diseasetreated in UNHAS Teaching Hospitalas much as 40 people. Analyzed data use Chi-square and Mann-Whitney tests.

Results: This study showed that there was no effect between the number of comorbidities, the duration of the illness, pharmaceutical use and the psychological status on sleep quality in the elderly. The only risk that affects sleep quality in this study is gender, with a p-value of 0.049. Poor sleep quality is more common in older men than women.

Conclusion: Gender is being a predictor of sleep quality among elders. In contrast, other factors do not affect sleep quality. For further research, the reseacrhers suggest that study should be conducted in large number of participants.

Keywords: Sleep quality; elderly; gender

$\llbracket$ Corresponding author: yodang.usnkolaka@gmail.com

Diajukan 22 Januari 2021 Diperbaiki 17 Mei 2021 Diterima 25 Februari 2021

https://jurnal.ugm.ac.id/jkesvo Published online February 28, 2021 
PENDAHULUAN

Penyakit kronis telah menjadi permasalahan kesehatan sekaligus menjadi penyebab kematian terbesar di dunia. Pada tahun 2014, penyakit kronis telah menyebabkan sekitar 36 juta kematian secara global. Penyakit kronis penyebab utama kematian secara global adalah penyakit jantung dan pembuluh darah, keganasan, penyakit pernapasan kronis, dan penyakit metabolik seperti diabetes (WHO, 2018).

Data Riskesdas pada tahun 2013, menujukkan bahwa penyakit kronis juga merupakan penyebab utama kematian di Indonesia (Riskesdas, 2018). Penyakit kronis yang paling sering terjadi dan dapat diderita pasien lanjut usia (lansia) adalah penyakit kardiovaskular, kanker, diabetes, penyakit pernapasan kronis, asma, penyakit ginjal kronis, radang sendi, alergi, katarak, osteoporosis, dan penyakit mental seperti penyakit Alzheimer (WHO, 2018).

Penyakit kronis yang diderita pasien lansia dapat menyebabkan banyak perubahan, baik pada kondisi fisik maupun psikologis pasien. Salah satu kondisi psikofisiologis pasien lansia dengan penyakit kronis yang terganggu adalah kualitas tidur. Selain proses penuaan yang terjadi secara fisiologis, penyakit kronis yang diderita pasien lansia dapat menambah penurunan kualitas tidurnya (Bernell \& Howard, 2016).

Proses penuaan yang dialami lansia menjadi penyebab kejadian dan dapat meningkatkan keparahan insomnia. Lansia mengalami struktur, durasi, kedalaman, dan kontinuitas tidur yang berubah dari kondisi sebelumnya (Eliopoulos, 2018). Lansia mengalami tidur yang lebih pendek, lebih ringan, dan lebih terputus-putus. Secara fisiologi, lansia lebih banyak masuk ke dalam tidur fase 1 dan 2, dan lebih sedikit masuk ke dalam tidur fase 3 dan 4 . Lansia memiliki durasi tidur rata-rata lebih pendek dibandingkan dengan dewasa muda (Ruiter et al., 2009).

Perubahan fisiologi tidur yang dialami lansia merupakan bagian normal dari proses penuaan dan menjadi penyebab gangguan tidur primer. Namun, penyebab gangguan tidur sekunder, seperti penyakit kronis yang dialami lansia, perlu mendapatkan perhatian khusus. Penegakan diagnosis gangguan tidur pada lansia secara tepat, dapat membuat penatalaksanaan gangguan tidur pada lansia juga menjadi lebih tepat dan dapat meningkatkan kualitas tidur lansia (Yaremchuk, 2018).

Faktor penyebab yang terkait kualitas tidur lansia perludikaji lebih dalam untuk menentukan tatalaksana yang tepat (Widasari et al., 2020). Faktor lingkungan, seperti cahaya dan kebisingan merupakan salah satu faktor penyebab gangguan tidur lansia (Ruiter et al., 2009).

Kualitas tidur pasien lansia juga dapat dipengaruhi oleh tingkat depresi dan rendahnya aktivitas fisik yang dilakukan pasien lansia (Wu et al., 2012). Hasil penelitian lainnya juga menunjukkan depresi pada lansia menyebabkan kualitas tidur menjadi berkurang (Chang et al., 2014). Faktor lainnya adalah keluhan nyeri dapat menurunkan kualitas tidur pasien lansia, baik lansia yang memiliki kognitif normal, memiliki gangguan kognitif ringan, ataupun lansia dengan demensia (Azri et al., 2016).

Selain itu, penelitian lain menyebutkan gangguan kognitif pada lansia dapat memperburuk kualitas tidurnya (Amer et al., 2013). Penyakit kronis seperti kanker yang dialami lansia dapat memberikan pengalaman nyeri yang dapat merubah kualitas tidur pasien lansia tersebut, meskipun hal ini juga dapat terjadi pada usia dewasa muda (Eyigor et al., 2010).

Hasil penelitian melaporkan bahwa kualitas tidur dan kematian tidak memiliki hubungan yang signifikan, tetapi durasi tidur yang panjang dapat dikaitkan 
dengan risiko kematian pada cardiovascular disease (CVD) pada lansia dengan kualitas tidur yang buruk (Suzuki et al., 2009). Penelitian lain menyebutkan lanisa yang memiliki kualitas tidur rendah akan mempengaruhi kualitas hidupnya (Tel, 2013).

Pasien lansia dengan penyakit kronis dapat mengalami gangguan tidur sehingga menyebabkan kualitas tidur yang buruk yang meningkatkan morbiditas dan mortalitas (Praharaj et al., 2018). Penelitian faktor penyebab yang mempengaruhi kualitas tidur pasien lansia dengan penyakit kronis belum banyak dilakukan sehingga penelitian ini dapat menambah bukti untuk menunjang dalam penegakan diagnosis dan tatalaksana intervensi terhadap kualitas tidur yang buruk menjadi lebih tepat.

Penelitian ini bertujuan untuk menganalisis kualitas tidur beserta faktorfaktor yang berpengaruh terhadapnya pasien lanjut usia dengan penyakit kronis diRS Unhas Makassar. Adapun faktorfaktor yang diteliti secara khusus adalah faktor psikologis, komorbid, lama penyakit kronis, dan penggunaan obatobatan.

\section{METODE}

Desain penelitian yang digunakan pada pada penelitian ini yaitu deskriptif analitik dengan metode survey crosssectional.Populasi penelitian ini yaitu pasien kategori lanjut usia yang dirawat di RS Unhas Makassar yang didiagnosis menderita penyakit kronis. Pemilihan sampel dilakukan secara non probability dengan menggunakan teknik total sampling. Penelitian ini dilakukan selama dua bulan yaitu bulan Oktober sampai November 2020.

Jumlah sampel yang terlibat dalam penelitian ini adalah sebanyak 40 orang. Sampel dipilih berdasarkan kriteria inklusi, yaitu berusia di atas 60 tahun, lansia dengan penyakit kronis, lansia yang dapat berkomunikasi verbal. Sebaliknya, kriteria eksklusi yaitu lansia yang mengalami penuruan kesadaran, lansia yang mengalami penuruan fungsi kognitif, tidak bersedia menjadi responden.

Pengumpulan data kualitas tidur menggunakan kuesioner Pittsburg Sleep Quality Index yang telah diadaptasi ke Bahasa Indonesia (Buysse et al., 1989; Khasanah \& Hidayati, 2012). Analisis data menggunakan uji statistic Chi-square untuk varibel 2 × 2, dan uji Mann-whitney untuk variable K x 2 (Dahlan, 2016). Penelitian ini telah mendapatkan persetujuan etik penelitian yang dikeluarkan oleh Fakultas Kedokteran Universitas Hasanuddin dengan nomor etik: 547/UN4.6.4.5.31/ PP36/2020.

\section{HASIL DAN PEMBAHASAN}

\section{Karakteristik Responden}

Hasil temuan pada penelitian kualitas tidur lansia selama bulan OktoberNovember 2020 didapatkan data sosiodemografi responden yang digambarkan pada Tabel 1 sebagai berikut.

Tabel 1. Sosio-demografi responden

\begin{tabular}{|c|c|c|c|}
\hline No & Karakteristik & $\begin{array}{l}\text { Frekuensi } \\
\text { (n) }\end{array}$ & $\begin{array}{c}\text { Presentase } \\
(\%)\end{array}$ \\
\hline \multirow[t]{3}{*}{1} & Usia & & \\
\hline & $\begin{array}{l}\text { a. Lansia akhir (60-64 } \\
\text { Tahun) }\end{array}$ & 22 & 55 \\
\hline & $\begin{array}{l}\text { b. Masa manula (>64 } \\
\text { Tahun) }\end{array}$ & 18 & 45 \\
\hline \multirow[t]{3}{*}{2} & Jenis kelamin & & \\
\hline & a. Laki-laki & 17 & 42,5 \\
\hline & $\begin{array}{l}\text { b. Perempuan } \\
\text { Tingkat pendidikan }\end{array}$ & 23 & 57,5 \\
\hline \multirow{3}{*}{3} & a. Rendah & 19 & 47,5 \\
\hline & b. Menengah & 14 & 35 \\
\hline & c. Tinggi & 7 & 17,5 \\
\hline \multirow[t]{5}{*}{4} & Pekerjaan & & \\
\hline & a. Tidak bekerja & 26 & 65 \\
\hline & b. Petani & 4 & 10 \\
\hline & c. Pedagang & 8 & 20 \\
\hline & d. Buruh harian & 2 & 5 \\
\hline \multirow[t]{4}{*}{5} & Penghasilan & & \\
\hline & $\begin{array}{l}\text { a. Tidak } \\
\text { berpenghasilan }\end{array}$ & 18 & 45 \\
\hline & b. $<2$ juta & 10 & 25 \\
\hline & c. $>2$ juta & 12 & 30 \\
\hline \multirow[t]{3}{*}{6} & Status pernikahan & & \\
\hline & a. Menikah & 22 & 55 \\
\hline & b. Cerai mati & 18 & 45 \\
\hline
\end{tabular}

Tabel 1. menunjukkan bahwa responden didominasi dari kelompok usia lansia akhir (60-64 tahun) sebanyak 55\% dan perempuan (57,5\%). Selain itu, 
Analisis Faktor-Faktor yang Memengaruhi Kualitas...

sebagian besar berlatar belakang pendidikan rendah $(47,5)$, tidak bekerja (65\%), tidak berpenghasilan (45\%), dan hampir setengah responden sudah tidak memiliki pasangan hidup (45\%). Adapun riwayat kesehatan lansia digambarkan pada Tabel 2 berikut.

Tabel 2. Ditribusi riwayat kesehatan lansia

\begin{tabular}{|c|c|c|c|}
\hline No & Riwayat & $\mathbf{n}$ & $\%$ \\
\hline \multirow[t]{6}{*}{1} & Jenis Penyakit Kronis & & \\
\hline & $\begin{array}{l}\text { a. Kardiometabolik (Hipertensi, } \\
\text { DM, gagal jantung) }\end{array}$ & 35 & 58,3 \\
\hline & b. Gangguan Neurologis & 6 & 10 \\
\hline & c. Keganasan & 7 & 11,7 \\
\hline & d. Ganguan Fungsi Ginjal & 5 & 8,3 \\
\hline & $\begin{array}{l}\text { e. Penyakit pernafasan (TBC, } \\
\text { Pneumonia, Efusi Pleura) }\end{array}$ & 7 & 11,7 \\
\hline \multirow[t]{3}{*}{2} & Penyakit Komorbid & 20 & 50 \\
\hline & a. Tidak memiliki komorbid & 12 & 30 \\
\hline & $\begin{array}{l}\text { b. Komorbid } 1 \\
\text { c. Komorbid }>1\end{array}$ & 8 & 20 \\
\hline \multirow[t]{3}{*}{3} & Lama Penyakit & 15 & 37,5 \\
\hline & a. $<1$ tahun & 8 & 20 \\
\hline & $\begin{array}{l}\text { b. } 1-5 \text { tahun } \\
\text { c. }>5 \text { tahun }\end{array}$ & 17 & 42,5 \\
\hline \multirow[t]{7}{*}{4} & Obat-obatan yang Digunakan & 35 & 67,3 \\
\hline & b. Statin & 4 & 7,7 \\
\hline & c. Analgesic & 4 & 7,7 \\
\hline & d. Antihistamin & 3 & 5,7 \\
\hline & e. Ekspectoran & 2 & 3,8 \\
\hline & f. Kortikosteroid & 1 & 1,9 \\
\hline & g. Antidepresan & 3 & 5,7 \\
\hline \multirow[t]{4}{*}{5} & Status Psikologi & & \\
\hline & a. Distres Ringan (0-4) & 5 & 12,5 \\
\hline & b. Distres Sedang (5-9) & 34 & 85 \\
\hline & c. Distres Berat (10-12) & 1 & 2,5 \\
\hline \multirow[t]{3}{*}{6} & Kualitas tidur & & \\
\hline & a. Buruk (skor >10) & 21 & 52,5 \\
\hline & b. Baik (skor <10) & 19 & 47,5 \\
\hline
\end{tabular}

Tabel 2 menampilkan bahwa mayoritas responden memiliki penyakit kronis jenis kardiometabolik yang mencakup hipertensi, diabetes mellitus, dan gagal jantung sebanyak 58,3\%. Sekalipun $50 \%$ responden tidak memiliki penyakit penyerta, tetapi sekitar 20\% responden memiliki penyakit penyerta lebih dari 1 jenis penyakit. Berdasarkan lama penyakit yang diderita, mayoritas responden $(42,5 \%)$ melaporkan telah menderita penyakit $>5$ tahun.

Jenis obat-obatan yang dominan digunakan adalah obat antihipertensi, yaitu $67,3 \%$ dari total responden. Gangguan psikologis yang dialami mayoritas berupa distress sedang sebanyak $85 \%$, dengan $52,5 \%$ dari responden melaporkan mengalami kualitas tidur yang buruk.

\section{Hubungan Karakteristik / Variable dengan Kualitas Tidur}

Beberapa karakteriktik responden seperti kategori usia, jenis kelamin, pendidikan, pekerjaan, penghasilan, status perkawinan, jumlah komorbid, lama penyakit, dan status psikologis dianalisis lanjut. Tujuannya adalah untuk menilai apakah karakteristik tersebut memiliki pengaruh pada kualitas tidur pasien lansia yang menderita penyakit kronis.

Tabel 3. Hubungan karakteristik/variable dengan kualitas tidur

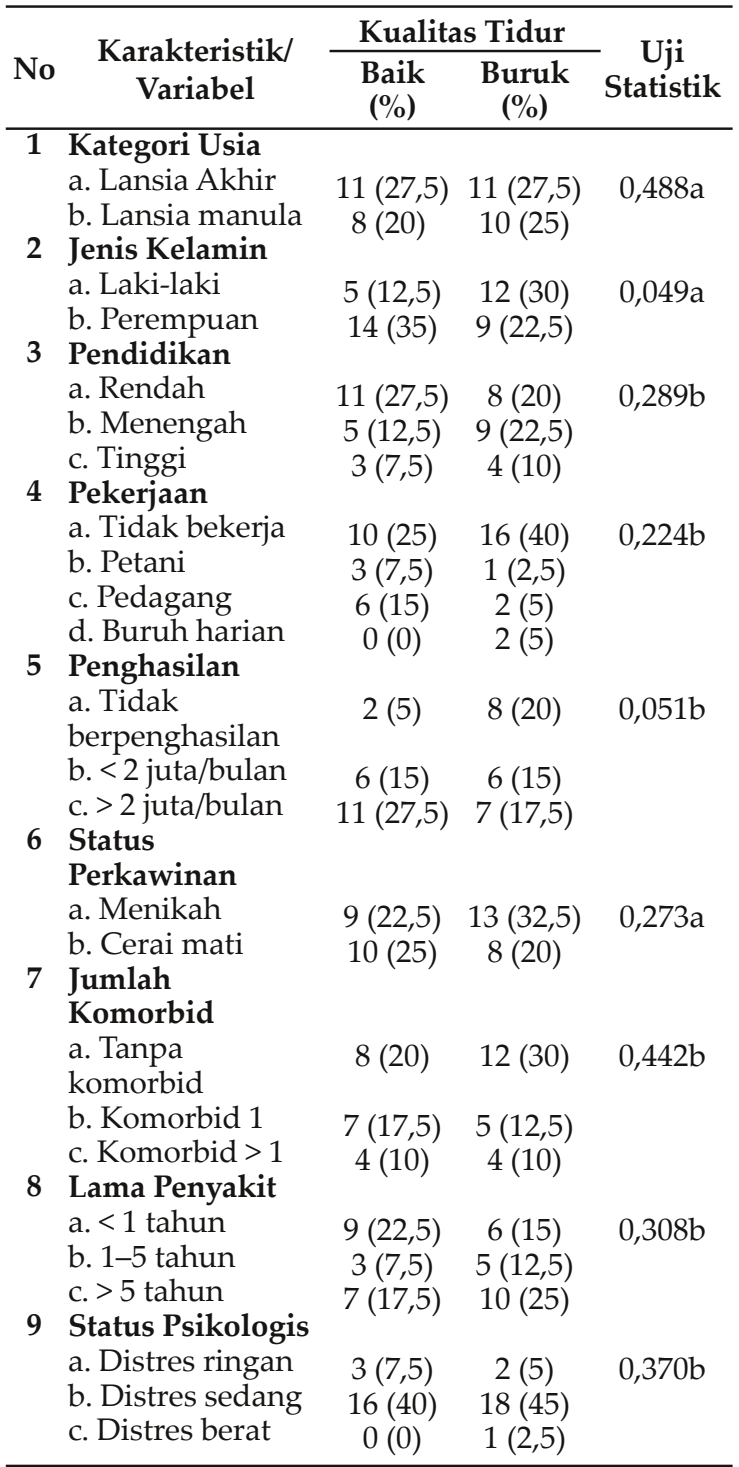

Chi-square test

b Mann-whitney 
Kualitas Tidur dengan Usia

Berdasarkan karakteristik usia responden, pada penelitian ini menunjukkan bahwa usia tidak berpengaruh bermakna dengan kualitas tidur buruk pasien ( $p$-value $=0,488$ ). Hal ini kemungkinan diakibatkan oleh jumlah responden kategori lansia akhir (60-64 tahun) lebih banyak jika dibandingkan dengan responden yang berusia $>65$ tahun dengan rasio perbandingan sekitar 55:45, dengan usia tertinggi berada pada 78 tahun.

Penelitian lain yang dilakukan oleh Rudimin et al., (2017) ditemukan bahwa kualitas tidur yang buruk didominasi oleh responden dengan usia kategori usia dewasa tua (75-90 tahun) sebanyak 41 orang $(65,1 \%)$. Selain itu, penelitian yang dilakukan oleh Khasanah \& Hidayati (2012) menunjukkan terdapat 49 lansia dari 75 responden memiliki kualitas tidur yang buruk dimana rentang usia lansia tersebut berada pada usia 60-74 tahun.

Berdasarkan hal tersebut dapat disimpulkan bahwa makin tua usia lansia, makin menurun kualitas tidurnya. Hal tersebut disebabkan karena saat seseorang mengalami pertambahan usia akan terjadi hubungan timbal balik terhadap keadaan fisik.

Pertambahan usia seseorang mempengaruhi penurunan kualitas fungsi semua organ, baik dari segi sistem pernapasan, pencernaan, penglihatan, pendengaran, hingga sistem kardiovaskuler. Hal ini menyebabkan timbulnya beragam keluhan pada lansia saat akan beristirahat yang berdampak pada penurunan kualitas tidur. Namun, hasil penelitian yang dilakukan oleh Silvanasari, (2012) menemukan tidak adanya perbedaan rerata kualitas tidur berdasarkan usia pasien.

\section{Kualitas Tidur dengan Jenis Kelamin}

Kualitas tidur yang buruk pada penelitian ini didominasi oleh lansia berjenis kelamin laki-laki, sekalipun dominasi responden adalah perempuan sekitar 57,5\%. Berdasarkan uji statistik menggunakan uji Chi-square ditemukan nilai $p$-value $=0,049$. Hal ini menunjukkan bahwa jenis kelamin memiliki hubungan terhadap kualitas tidur pada lansia.

Hal ini berbeda dengan hasil penelitian yang dilakukan Khasanah \& Hidayati (2012) yang menunjukkan responden perempuan cenderung memiliki kualitas tidur yang buruk. Namun responden penelitian ini didominasi oleh jenis kelamin perempuan sehingga berpengaruh terhadap hasil penelitian. Kualitas tidur yang buruk pada kelompok lansia laki-laki kemungkinan di akibatkan oleh adanya perubahan kadar hormone testosterone. Wittert (2014).

Proses menua mempengaruhi produksi hormone testosterone di malam hari, dimana laki-laki lansia akan memproduksi sedikit testosterone dibandingkan dengan laki-laki dewasa muda. Lebih lanjut, Wittert menjelaskan bahwa penurunan jumlah testosterone menunjukkan efek terhadap tidur, dimana berdasarkan hasil penelitian kohort di temukan pada kelompok lansia laki-laki berusia 65 tahun ke atas yang memiliki kadar testosterone yang rendah cenderung mengalami penurunan efisiensi tidur, terbangun dimalam hari yang lebih sering, dan berkurangnya waktu tidur gelombang lambat (Wittert, 2014).

\section{Kualitas Tidur dengan Tingkat Pendidikan}

Mayoritas responden didominasi dari tingkatan pendidikan rendah dengan persentase 47,5 dari total responden. Sekitar $42,5 \%$ responden yang mengalami kualitas tidur yang buruk merupakan lansia dengan kaulifikasi pendidikan rendah dan menengah. Uji statistik Mannwhitney menunjukkan $p$-value $=0,289$, yang berarti tidak ada hubungan antara tingkat pendidikan dengan kualitas tidur lansia.

Sekalipun penelitian ini tidak menganalisis mengenai hubungan tingkat 
pendidikan dengan pengetahuan lansia terkait dengan dengan gangguan tidur, tetapi hasil penelitian sebelumnya melaporkan tingkat pendidikan memiliki korelasi terhadap tingkat kecerdasan. Kecerdasan yang dimaksud bukan hanya kecerdasan intelektual saja, melainkan juga kecerdasan dalam mengelola emosi. Hal ini didukung oleh penelitian yang dilakukan Gusmao et al. (2018) yang melaporkan bahwa lansia $(84,4 \%)$ dengan kecerdasan emosional sedang memiliki kualitas tidur yang baik.

Selain pendidikan formal, pendidikan non formal juga turut berpengaruh terhadap kualitas tidur. Berdasarkan hasil studi yang di lakukan oleh Chen et al., (2010) pada kelompok wanita pekerja, dengan melakukan edukasi sleep hygiene selama 5 minggu, para responden menunjukkan peningkatan kemampuan mengelola lingkungan tempat tidur, kebiasaan tidur, dan distress emosional di akhir penelitian sehingga berdampak pada peningkatan kualitas tidur.

Hal tersebut didukung oleh hasil penelitian pada kelompok pasien yang menjalani hemodialysis. Kelompok pasien tersebut diberi intervensi berupa edukasi sleep hygiene dengan dan tanpa behavioral therapy. Di akhir penelitian, ditemukan terjadinya penurunan skor PSQI pada kedua kelompok intervensi yang menunjukkan bahwa edukasi dapat meningkatkan pengetahuan pasien terkait tata kelola gangguan tidur sehingga dapat meningkatkan kualitas tidurnya (Soleimani et al., 2016).

\section{Kualitas Tidur dengan Pekerjaan}

Dominasi pasien lansia merupakan seseorang yang sudah tidak bekerja lagi, sedangkan untuk lansia dengan kualitas tidur buruk didominasi oleh mereka yang tidak bekerja. Uji statistik Mann-whitney menunjukkan $p$-value $=0,224$, yang berarti tidak ada hubungan antara pekerjaan dengan kualitas tidur. Secara fisiologis, bekerja menghasilkan gerakan tubuh, intensitas, durasi dan frekuensi kontraksi otot yang tentunya akan berpengaruh terhadap kualitas tidur seseorang.

Sebagaimana hasil penelitian Fauziah (2018) melaporkan bahwa terdapat hubungan antara aktivitas fisik yang dilakukan dengan kualitas tidur pada lansia. Makin tinggi aktivitas fisik yang dilakukan, makin buruk kualitas tidurnya karena ketika bekerja lansia menggunakan kapasitas fisiknya melebihi batas kemampuan fisik lansia sehingga menyebabkan kelelahan yang dapat memengaruhi kualitas istirahat.

Akan tetapi, ketika lansia tidak bekerja, cenderung mengakibatkan mereka menghabiskan lebih banyak waktu untuk memikirkan suatu hal yang tidak perlu sehingga menyebabkan timbulnya masalah psikologis berupa kecemasan dan depresi. Hal ini didukung oleh hasil penelitian yang dilakukan oleh Dariah \& Okatiranti (2015) yang menyatakan adanya hubungan antara tingkat kecemasan dan kualitas tidur lansia, di mana makin tinggi tingkatan kecemasan yang dialami lansia, maka makin buruk pula kualitas tidur.

\section{Kualitas Tidur dengan Penghasilan}

Hasil penelitian menunjukkan dominasi lansia yang tidak bekerja juga didominasi oleh lansia yang tidak berpenghasilan. Namun secara persentase, tidak ada perbedaan bermakna antara lansia yang tidak berpenghasilan dengan lansia yang berpenghasilan dalam mempengaruhi kualitas tidur ( $p$-value $=$ 0,051).

Mengenai hubungan ataupun pengaruh penghasilan terhadap kualitas tidur, hingga saat ini belum ditemukan referensi yang relevan untuk mendukung hasil penelitian ini. Oleh karena itu, penelitian ini turut berkontribusi terhadap tersedianya informasi yang berkenaan dengan penghasilan dan kualitas tidur terkhusus pada kelompok lanjut usia. 
Analisis Faktor-Faktor yang Memengaruhi Kualitas...

\section{Kualitas Tidur dengan Status Perkawinan}

Penelitian ini menunjukkan bahwa sekitar 32,5\% lansia dengan status menikah, dan $20 \%$ lansia dengan status cerai mengalami kualitas tidur yang buruk. Uji statistik Chi-square menunjukkan $p$-value $=0,273$, yang berarti bahwa tidak ada pengaruh antara status perkawinan dengan kualitas tidur lansia.

Hal ini kemungkinan disebabkan oleh lansia yang memiliki status cerai tinggal bersama anaknya sehingga walaupun status perkawinan cerai mati, tetapi lansia masih dapat hidup bersama dengan keluarganya, yaitu anak. Namun, penelitiansebelumnya yang dilakukan pada kelompok lansia di Kanada dengan melibatkan 2468 responden menemukan bahwa salah satu faktor yang mempengaruhi efisiensi tidur yang berdampak pada penurunan kualitas tidur adalah status perkawinan (Desjardins et al., 2019).

\section{Kualitas Tidur dengan Faktor Komorbid}

Analisis kualitas tidur berdasarkan faktor komorbid dapat disimpulkan bahwa tidak terdapat pengaruh. Hal ini ditunjukkan dengan hasil uji statistik Mann-whitney $p$-value $=0,442$. Kondisi ini kemungkinan dipengaruhi oleh jumlah responden tanpa komorbid sekitar 50\% dari total responden sehingga hal tersebut turut mempengaruhi hasil uji statistik.

Sebaliknya, hasil penelitian yang dilakukan oleh Allen et al., (2013) menyatakan bahwa beberapa kondisi penyakit sebagai pemicu gangguan tidur pada lanjut usia yaitu demensia, nyeri kronis, penyakit paru dan gangguan genitourinary. Selain itu, hasil penelitian Chiang et al., (2018) melaporkan bahwa lanjut usia di Singapura dengan masalah kardometabolik seperti diabetes mellitus, hipertensi dan dyslipidemia yang disertai dengan keluhan nokturia meningkatkan resiko kualitas tidur yang buruk.

Hal menarik, penelitian Silvanasari
(2012) menyatakan bahwa salah satu faktor yang memengaruhi kualitas tidur rata-rata lansia adalah faktor respon terhadap penyakit yang diderita $(\mathrm{p}$ value $=$ 0,005). Penelitian tersebut menunjukkan bahwa frekuensi kualitas tidur yang buruk lebih tinggi pada lansia yang sakit $(11,33 \%)$ dibandingkan pada lansia yang tidak sakit $(7,58 \%)$.

\section{Kualitas Tidur dengan Faktor Lama Penyakit}

Berdasarkan Tabel 3 terkait analisis data pengaruh faktor lama penyakit terhadap kualitas tidur dengan menggunakan uji Mann-whitney, ditemukan hasil $p$-value $=0,308$, maka dapat disimpulkan bahwa tidak ada pengaruh lama penyakit terhadap kualitas tidur pada lansia. Namun, hasil penelitian yang dilakukan oleh Ozturk et al. (2015) melaporkan bahwa pasien diabetesdengan durasi atau lama penyakit mempengaruhi kualitas tidur pasien lanjut usia.

Intensitas gangguan tidur yang paling banyak dialami responden selama 1 bulan terakhir adalah mengalami keluhan terpaksa bangun ke kamar mandi yang dialami kurang dari 1 kali seminggu. Selain itu, keluhan insomnia di mana lansia tidak dapat tidur walau sudah berbaring selama 30 menit atau lebih selama 1-2 kali seminggu dan keluhan batuk atau mendengkur dengan keras selama lebih dari 3 kali seminggu.

Pernyataan tersebut didukung oleh hasil penelitian Silvanasari (2012) yang melaporkan bahwa lansia dengan penyakit asma mengalami keluhan napas yang tidak nyaman di malam hari. Selain itu, lansia dengan hipertensi menyatakan sulit untuk tertidur karena perasaan pusing di malam hari dan lansia dengan diabetes mellitus menyatakan seringkali ingin berkemih dan haus di malam hari.

\section{Kualitas Tidur dengan Faktor Psikologi}

Berdasarkan Tabel 3 terkait analisis data faktor psikologi terhadap kualitas 
tidur dengan menggunakan uji Mannwhitney ditemukan nilai $\mathrm{p}=0,370$ sehingga dapat disimpulkan bahwa tidak ada pengaruh faktor psikologis dengan kualitas tidur lansia. Hoyos et al. (2020) menemukan bahwa gangguan psikologis dapat mempengaruhi irama sirkadian para lanjut usia, tetapi hal tersebut sangat kecil pengaruhnya terhadap kualitas tidur.

Hal serupa yang dikemukakan oleh Ozturk et al. (2015), di mana hasil penelitian pada kelompok pasien diabetes yang disertai dengan komplikasi penyakit makrovaskular melaporkan kualitas tidur yang buruk. Namun di satu sisi, buruknya kualitas tidur juga meningkatkan depresi pasien sehingga hubungan antara kualitas tidur dengan depresi disimpulkan bahwa kedua-duanya di akibatkan oleh kondisi penyakit pasien.

Pasien lansia dengan distress sedang memiliki kualitastidur yang lebih buruk banding lansia dengan distress ringan. Hal ini didukung oleh penelitian Silvanasari (2012) yang melaporkan bahwa kecemasan $(\mathrm{p}$-value $=0,005)$ dan depresi $(\mathrm{p}$-value $=$ 0,005) memiliki hubungan terhadap kualitas tidur lansia. Penelitian tersebut menunjukkan bahwa lansia yang cemas memiliki kualitas tidur yang buruk lebih tinggi jika disbanding yang tidak cemas.

\section{PENUTUP}

\section{Kesimpulan}

Berdasarkan studi yang dilakukan dapat disimpulkan bahwa jenis kelamin memiliki pengaruh terhadap kualitas tidur pada lansia. Pada usia, tingkat pendidikan, pekerjaan, penghasilan dan status perkawinan, komorbiditas, lama penyakit, dan status psikologis secara statistik menunjukkan tidak ada pengaruhnya terhadap kualitas tidur lansia.

\section{Saran}

Sebagian besar karakteristik responden beserta variable yang diteliti menunjukkan tidak ada pengaruhnya terhadap kualitas tidur lansia, maka peneliti menyarankan untuk melakukan penelitian dengan melibatkan jumlah responden yang lebih besar. Mengingat responden yang terlibat pada penelitian ini sangat kecil, hal tersebut dimungkinkan dapat mempengaruhi hasil akhir penelitian ini. Penelitian lebih lanjut dengan jumlah sampel yang lebih besar sangat dianjurkan untuk menunjukkan hasil yang lebih akurat dan tingkat evidence yang lebih baik.

\section{DAFTAR PUSTAKA}

Allen, A. M., Coon, D. W., Uriri-Glover, J., \& Grando, V. (2013). Factors associated with sleep disturbance among older adults in inpatient rehabilitation facilities. Rehabilitation Nursing, 38(5). https://doi.org/10.1002/ rnj.88

Amer, M. S., Hamza, S. A., El Akkad, R. M., \& Abdel Galeel, Y. I. I. (2013). Does self-reported sleep quality predict poor cognitive performance among elderly living in elderly homes? Aging and Mental Health. https://doi.org/ 10.1080/13607863.2013.790930

Azri, M. A., Dahlan, A., Masuri, M. G., \& Isa, K. A. M. (2016). Sleep Quality among Older Persons in Institutions. Procedia - Social and Behavioral Sciences. https://doi.org/10.1016/ j.sbspro.2016.10.221

Becker, N. B., Neves, S., Jesus, D., Viseu, J. N., Dieter, C., Guerreiro, M., \& Domingues, R. B. (2018). Depression and quality of life in older adults: Mediation effect of sleep quality. International Journal of Clinical and Health Psychology, 18(1), 8-17. https:// doi.org/10.1016/j.ijchp.2017.10.002

Bernell, S., \& Howard, S. W. (2016). Use Your Words Carefully: What Is a Chronic Disease? Frontiers in Public Health, 4. https://doi.org/10.3389/ fpubh.2016.00159 
Buysse, D. J., Reynolds, C. F., Monk, T. H., Berman, S. R., \& Kupfer, D. J. (1989). The Pittsburgh sleep quality index: A new instrument for psychiatric practice and research. Psychiatry Research, 28(2), 193-213. https://doi.org/ 10.1016/0165-1781(89)90047-4

Chang, K. J., Son, S. J., Lee, Y., Back, J. H., Lee, K. S., Lee, S. J., Chung, Y. K., Lim, K. Y., Noh, J. S., Kim, H. C., Koh, S. H., Roh, H. W., Park, M. A., Kim, J. J., \& Hong, C. H. (2014). Perceived sleep quality is associated with depression in a Korean elderly population. Archives of Gerontology and Geriatrics. https://doi.org/10.1016/

j.archger.2014.04.007

Chen, P., Kuo, H., \& Chueh, K. (2010). Sleep Hygiene Education: Efficacy on Sleep Quality in Working Women. Journal of Nursing Research, 18(4), 283$289 . \quad$ https://doi.org/10.1097/ JNR.0b013e3181fbe3fd

Chiang, G. S. H., Sim, B. L. H., Lee, J. J. M., \& Quah, J. H. M. (2018). Determinants of poor sleep quality in elderly patients with diabetes mellitus, hyperlipidemia and hypertension in Singapore. Primary Health Care Research \& Development, 19(6). https:// doi.org/10.1017/S146342361800018X

Dahlan, M. . (2016). Besar sampel dalam penelitian kedokteran dan kesehatan. Epidemiologi Indonesia.

Dariah, E. D., \& Okatiranti, O. (2015). Hubungan Kecemasan dengan Kualitas Tidur Lansia di Posbindu Anyelir Kecamatan Cisarua Kabupaten Bandung Barat. Jurnal Keperawatan BSI, 3(2).

Desjardins, S., Lapierre, S., Hudon, C., \& Desgagné, A. (2019). Factors involved in sleep efficiency: a population-based study of community-dwelling elderly persons. SLEEPJ, February, 1-10. https://doi.org/10.1093/sleep/zsz038

Eliopoulos, C. (2018). Gerontological Nursing Ninth Edition. Lippincott Williams \& Wilkins.
Eyigor, S., Eyigor, C., \& Uslu, R. (2010). Assessment of pain, fatigue, sleep and quality of life (QoL) in elderly hospitalized cancer patients. Archives of Gerontology and Geriatrics. https:// doi.org/10.1016/j.archger.2009.11.018

Fauziah, E. (2018). Pengaruh Pemberian Minyak Esensial Aromaterapi Kenanga Terhadap Kualitas Tidur Lansia Di Dusun Karang Tengah Nogotirto Gamping Sleman Yogyakarta. Universitas 'Aisyiyah Yogyakarta (UNISA).

Gusmao, T., Wiyono, J., \& Ardiyani, V. M. (2018). Hubungan Kualitas Tidur Dengan Kecerdasan Emosional Pada Lansia Di Posyandu Lansia Permadi Tlogosuryo Malang. Nursing News: Jurnal Ilmiah Keperawatan, 3(1).

Hoyos, C. M., Gordon, C., Terpening, Z., Norrie, L., Lewis, S. J. G., Hickie, I. B., \& Naismith, S. L. (2020). Circadian rhythm and sleep alterations in older people with lifetime depression: a case-control study. BMC Psychiatry, 20(1), 192. https://doi.org/10.1186/ s12888-020-02606-Z

Jehan, S., Masters-isarilov, A., Salifu, I., Zizi, F., Jean-, G., Pandi-perumal, S. R., Gupta, R., Brzezinski, A., \& Samy, I. (2015). Sleep Disorders in Postmenopausal Women. Journal of Sleep Disorders \& Therapy, 4(5).

Khasanah, K., \& Hidayati, W. (2012). Kualitas Tidur Lansia Balai Rehabilitasi Sosial " MANDIRI " Semarang. Jurnal Nursing Studies, 1(1), 189-196. http://ejournal-s1.undip.ac.id/ index.php/jnursing

Ozturk, Z. A., Yesil, Y., Kuyumcu, M. E., \& Savas, E. (2015). Association of depression and sleep quality with complications of type 2 diabetes in geriatric patients. Aging Clinical and Experimental Research, 27(4), 533-538. https://doi.org/10.1007/s40520-0140293-0

Praharaj, S. K., Gupta, R., \& Gaur, N. (2018). Clinical Practice Guideline on 
Management of Sleep Disorders in the Elderly. Indian Journal of Psychiatry, 60(Suppl 3), S383-S396. https://doi.org/ 10.4103/0019-5545.224477

Riskesdas, K. (2018). Hasil Utama Riset Kesehata Dasar (RISKESDAS). Journal of Physics A: Mathematical and Theoretical, 44(8), 1-200. https://doi.org/ 10.1088/1751-8113/44/8/085201

Rudimin, R., Hariyanto, T., \& Rahayu, W. (2017). Hubungan Tingkat Umur Dengan Kualitas Tidur Pada Lansia Di Posyandu Permadi Kelurahan Tlogomas Kecamatan Lowokwaru Malan. Nursing News: Jurnal Ilmiah Keperawatan, 2(1).

Ruiter, M. E., Vander Wal, G. S., \& Lichstein, K. L. (2009). Insomnia in the elderly. In Principles and Practice of Geriatric Sleep Medicine. https://doi.org/ 10.1017/CBO9780511770661.028

Silvanasari, I. A. (2012). Faktor-faktor yang berhubungan dengan kualitas tidur yang buruk pada lansia di Desa Wonojati Kecamatan Jenggawah Kabupaten Jember. Universitas Jember.

Soleimani, F., Motaarefi, H., \& Hasanpourdehkordi, A. (2016). Effect of Sleep Hygiene Education on Sleep Quality in Hemodialysis Patients. Journal of Clinical and Diagnostic Research: JCDR, 10(12), 10-13. https://doi.org/10.7860/ JCDR/2016/19668.8941

Suzuki, E., Yorifuji, T., Ueshima, K., Takao, S., Sugiyama, M., Ohta, T., IshikawaTakata, K., \& Doi, H. (2009). Sleep duration, sleep quality and cardiovascular disease mortality among the elderly: A populationbased cohort study. Preventive Medicine. https://doi.org/10.1016/ j.ypmed.2009.06.016

Tel, H. (2013). Sleep quality and quality of life among the elderly people. Neurology Psychiatry and Brain Research. $\quad$ https://doi.org/10.1016/ j.npbr.2012.10.002

WHO. (2018). Non-Communicable Diseases Fact Sheet. Public Health: An Action Guide to Improving Health. https://doi.org/10.1093/acprof:oso/ 9780199238934.003.15

Widasari, E. R., Tanno, K., \& Tamura, H. (2020). Automatic Sleep Disorders Classification Using Ensemble of Bagged Tree Based on Sleep Quality Features. Electronics, 9(3), 512. https:// doi.org/10.3390/electronics9030512

Wittert, G., 2014. The relationship between sleep disorders and testosterone in men. Asian Journal of Andrology, 16(2), p.262.

Wu, C. Y., Su, T. P., Fang, C. L., \& Yeh Chang, M. (2012). Sleep quality among community-dwelling elderly people and its demographic, mental, and physical correlates. Journal of the Chinese Medical Association. https:// doi.org/10.1016/j.jcma.2011.12.011

Yaremchuk, K. (2018). Sleep Disorders in the Elderly. In Clinics in Geriatric Medicine. https://doi.org/10.1016/ j.cger.2018.01.008 